\title{
The European Crisis: Repercussions on the Portuguese Economy
}

\author{
By Leonida Correia*
}

The recent economic and sovereign debt crisis strongly affected several European countries. This paper examines the implications on the Portuguese economy by exploring the effects of the crisis on the most relevant macroeconomic variables. We analyse the overall economic context in Portugal from the time it joined the euro until its bailout from Troika to understand the several factors that justify the need for the Economic and Financial Assistance Programme. Additionally, we investigate the repercussions of the crisis from 2008 onward, emphasizing the effects after 2011 that already include the impact of the austerity measures. Finally, we carry out an analysis of the projections in the medium term and we assess the challenges and opportunities for Portugal in the near future.

Keywords: Austerity, Crisis, Portugal.

\section{Introduction}

The recent crisis originated in the United States during the subprime credit problems in the summer of 2007 quickly spread, through multiple channels, to the world economy. This is considered the sharpest, most synchronous crisis across countries and the most global one since the Great Depression of the 1930s. Due to its impact of severe economic downturn around the world, this crisis is commonly known as the "Great Recession".

Since the beginning of the global financial crisis a substantial literature has extensively discussed and analysed the underlying causes and their implications. For example, the European Commission (2009) contains a chronological and historical perspective of the crisis, as well as an earlier analysis of its economic consequences, whereas the United Nations (2011) evaluated its ongoing adverse social consequences. Another related group of studies (for example, Claessens et al. 2009, 2010, Kenc and Dibooglu 2010) has proceeded to a historical comparison of the similarities and differences between the recent global crisis and previous ones. In general, they show that although there are some common features, including the presence of a similar stress in the financial system, the size and extent of the recent crisis are much greater than in other episodes that have occurred since the Great Depression. The Great Depression of the 1930s continues to be regarded as the longest, deepest and broadest crisis that the industrialized world has ever experienced (Grossman and Meissner 2010).

\footnotetext{
* Assistant Professor, ECHS/DESG/CETRAD - UTAD, Portugal.
} 
Recently, another dimension of the ongoing discussions about the global crisis has focused on its spread and cost for the European Union (EU). Specifically, a vast literature (for example, Obstfeld 2013, Santillán-Salgado 2013, Honkapohja 2014, Gibson et al. 2014, Papanikos 2014, Moro 2014) has addressed many important issues and topics related to the economic and sovereign debt crisis in the euro area, including its explanations, the policy options to deal with the prevailing problems and the lessons to draw for the future of the euro area. From this strand of literature emerges, among several others, a consensual conclusion that the European countries were affected to differing degrees depending on their economic structure and vulnerability to shocks. In particular, the peripheral countries, including Portugal, have become the most vulnerable to the vicissitudes of the crisis.

In Portugal, the crisis began to be evident in 2008, partly as a consequence of the international economic and financial crisis, but additionally due to existing internal macroeconomic imbalances and structural weaknesses rooted in the past.

The ensuing sovereign debt crisis in the euro area worsened the economic situation and, by May 2011, Portugal needed a bailout from the EU, the European Central Bank (ECB) and the International Monetary Fund (IMF). Until May 2014, Portugal was under the Economic and Financial Assistance Programme (EFAP), which led to several austerity measures to be put in place by the Portuguese government. According to numbers from OECD (2015), Portugal, as well as Greece and Ireland, announced a larger package of fiscal consolidation, above $10 \%$ of GDP.

The main objective of this paper is to analyse the repercussions of the recent crisis on the Portuguese economy. To achieve this goal the paper is organized as follows. Firstly the situation in Portugal from the adhesion to the euro area until the EFAP is examined, looking at the evolution of several relevant macroeconomic variables in the period of 1999-2010. Secondly the effects of the crisis from 2008 onward are evaluated, with particular attention paid to the period following the agreement between the Portuguese authorities and the Troika. Thirdly the challenges and opportunities for Portugal in the medium term are discussed. And finally there is a conclusion of the paper.

\section{Situation before the Economic and Financial Assistance Programme}

From the time Portugal joined the euro area until the EFAP, i.e. during the period 1999-2010, it has experienced poor performance of economic activity. Figure 1 shows weak economic growth since the 2000s ("the lost decade"), in which the GDP grew at an average rate of $1 \%$ per year, lower than the EU average, with negative consequences on the unemployment rate. In 2000 , both GDP growth and the unemployment rate had a value of $4 \%$. Since then, the evolution of these two variables has been unfavourable. 
Figure 1. GDP Growth and Unemployment, 1999-2010 (\%)

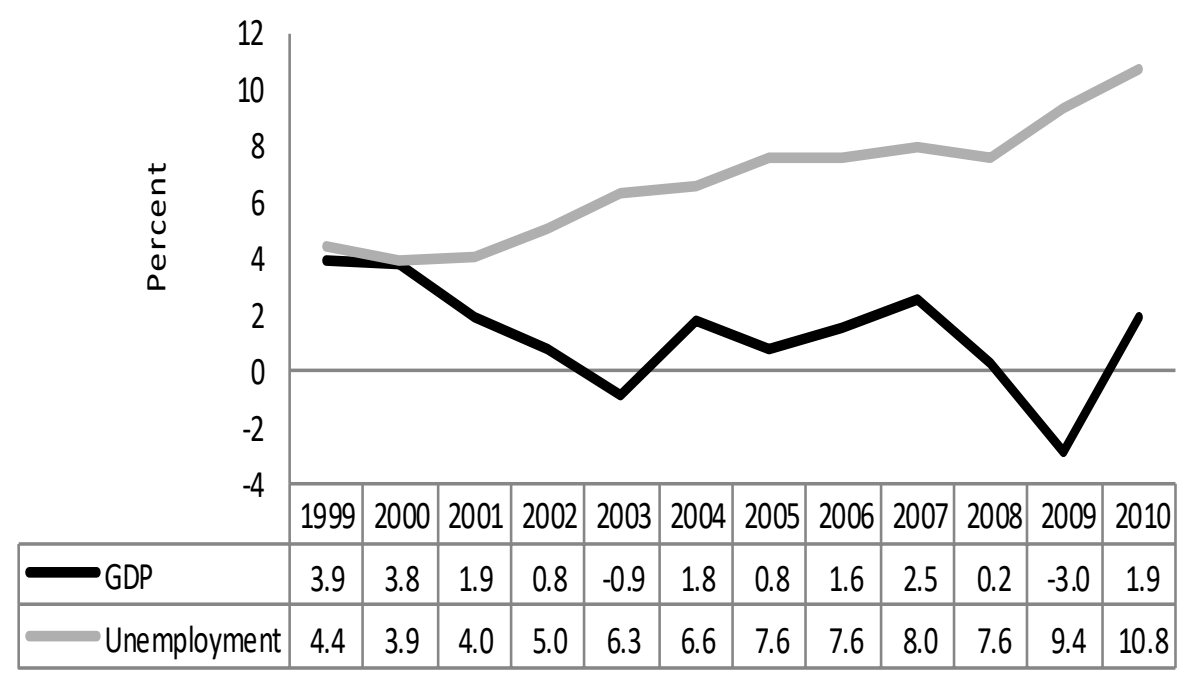

Source: Bank of Portugal (www. bportugal.pt) and National Statistics Office (www.ine.pt).

The excessive consumption growth was another problem because, in general, the expansion of consumption, both public and private, exceeded the GDP growth, due to the relatively low inflation and interest rates, and easy credit. The growth rate of public consumption was higher than that of private consumption, and both were higher than the growth of production (Figure 2).

Figure 2. Growth of GDP, Private and Public Consumption, 1999-2010 (\%)

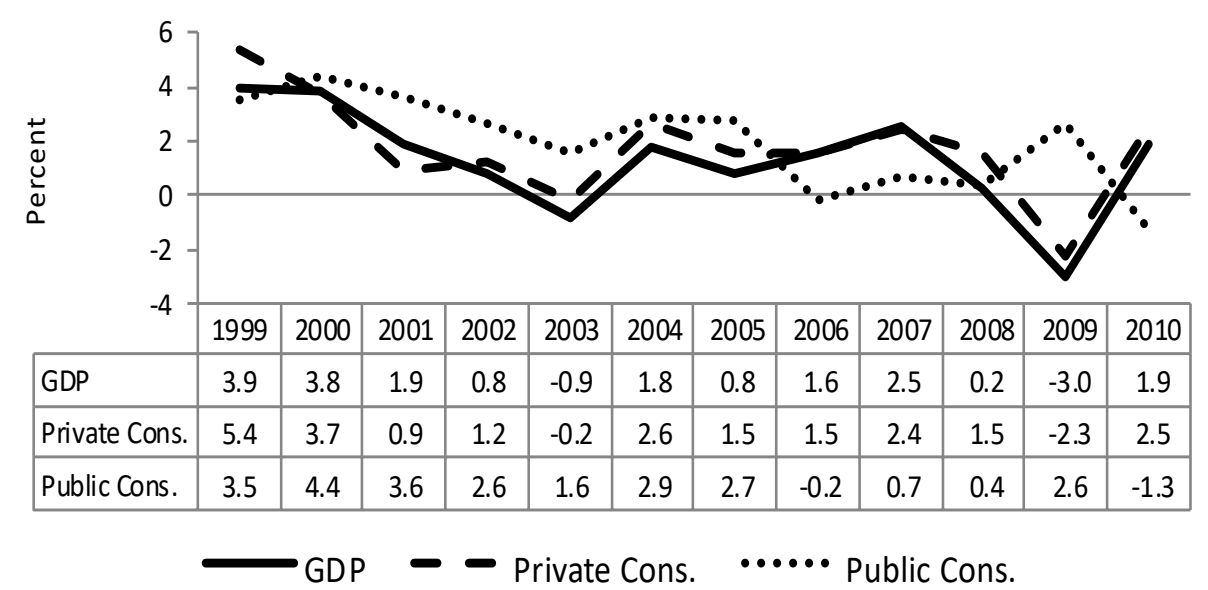

Source: Bank of Portugal (www.bportugal.pt).

The problems of international competitiveness were reflected in high current account deficits, averaging about $10 \%$ of GDP (Figure 3). Since 2000, the current account deficit (including the trade balance) moved closer to $10 \%$, except for in the years 2002 to 2004 . The accumulation of the external debt 
over time was exponential, which led to a gross external debt of $230 \%$ of GDP in 2010 (corresponding to a net value of $84 \%$ of GDP).

Figure 3. External Current Account, 1999-2010 (\% of GDP)

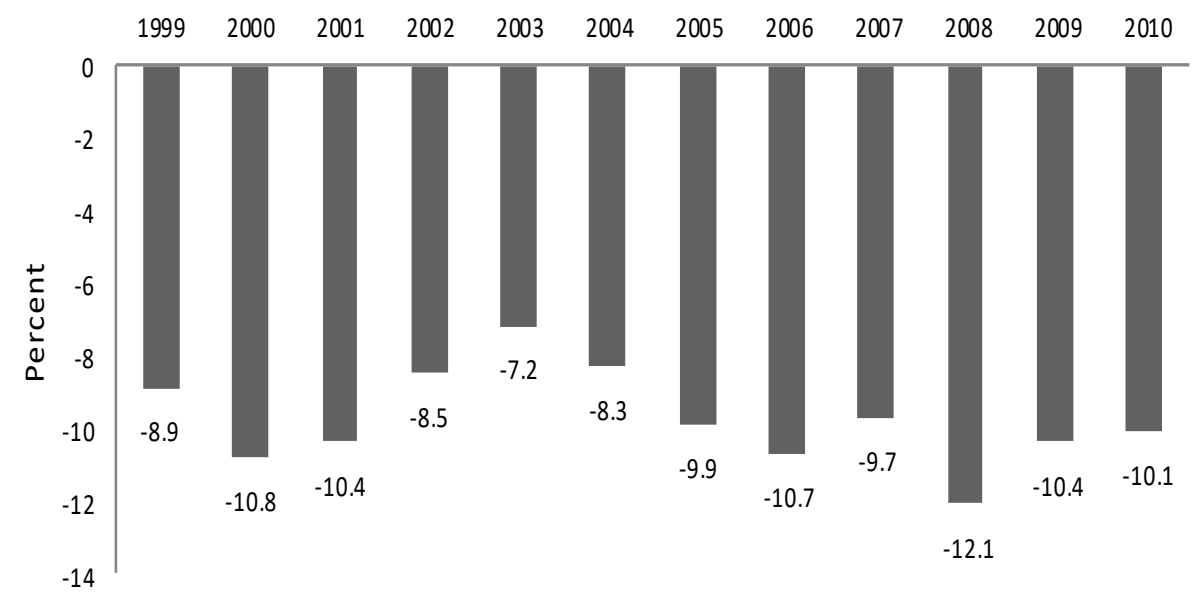

Source: Bank of Portugal (www.bportugal.pt).

In the same period, Portugal experienced a growing public indebtedness (Figure 4). Since 1999, the budget deficit was equal to or above $3 \%$ of GDP, and the public debt ratio displayed an increasing trend; since 2004, the public debt has exceeded $60 \%$ of GDP. The budget deficit was 3\% in 1999 and then worsened until 2005. It registered lower values in the period of 2006-2008, after which it climbed to about $10 \%$ in 2009 and $11 \%$ in 2010 . The public debt has grown dramatically: from 51\% of GDP in 1999 to $96 \%$ in 2010.

Figure 4. Overall Budget Balance and Public Debt, 1999-2010 (\% of GDP)
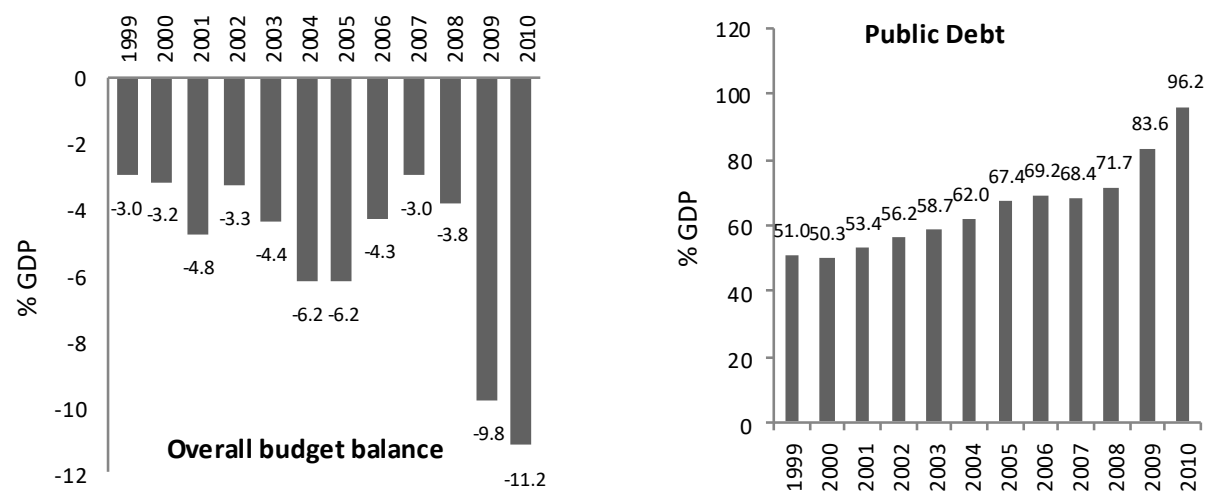

Source: Bank of Portugal (www.bportugal.pt).

With the creation of the euro, the risk of spread was levelled for all euro area countries, which was a sign of confidence from the financial markets. As a negative consequence of this sharp fall in the interest rates, excessive 
wastefulness resulted in some countries generating, as we have seen, difficult situations in their public accounts.

Another problem was the lower investment and savings (Figure 5). Until 2008, the levels of investment and savings of the households decreased their share in GDP persistently. Families and firms were gradually lowering their savings since the 1980s (which is not seen in the chart), which was translated to a domestic savings rate that was very low and insufficient to finance private investment.

Figure 5. Saving and Investment, 1999-2010 (\% of GDP)

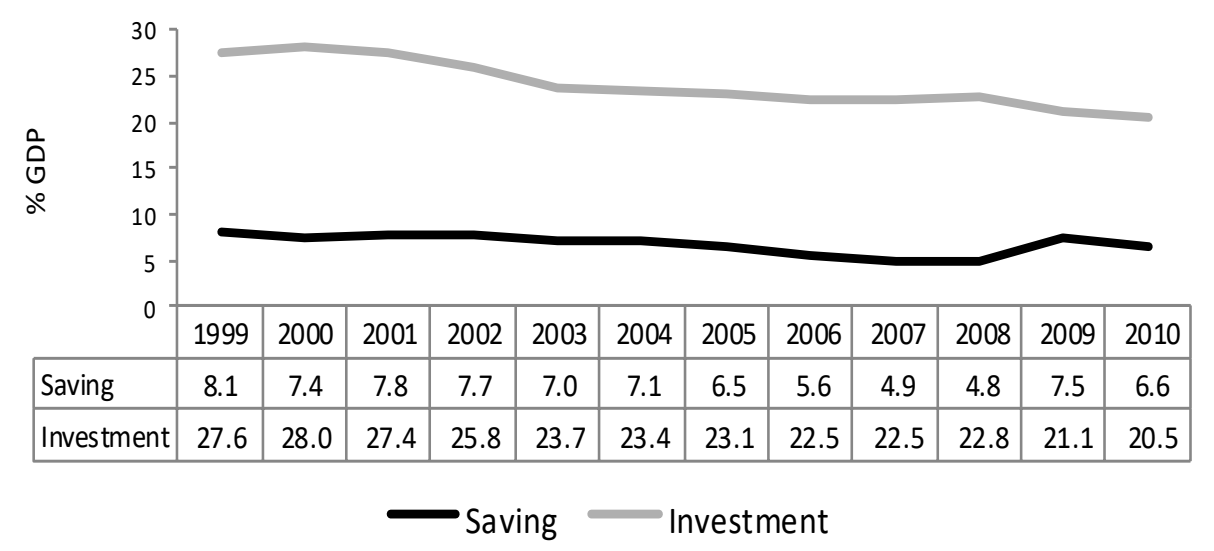

Source: PORDATA - Database of Contemporary Portugal (www.pordata.pt).

In summary, from the time Portugal joined the euro area until the sovereign debt crisis the economic and financial conditions deteriorated substantially, namely: the output growth slowed, the unemployment rate increased, the external current account deficit worsened, the government budget deficit grew, the public debt reached historic levels, and the investment and saving of households decreased.

\section{Repercussions of the Crisis on the Portuguese Economy}

In this section we evaluate the effects of the crisis after 2008 with a particular emphasis on the period after the agreement between the Portuguese authorities and the Troika.

\section{The Context}

As previously mentioned, the global financial and economic crisis has significantly aggravated the existing internal macroeconomic imbalances in the Portuguese economy. Such problems have left Portugal vulnerable to the volatility in the financial markets, which "went crazy" following the Greek crisis. The spread of the Portuguese sovereign debt has increased tremendously and Portuguese banks no longer have access to foreign credit. The combination 
of this range of factors led the Portuguese government at this time (Socialist Party) to make a request for financial assistance in April of 2011. ${ }^{1}$

The EFAP was agreed between the Portuguese authorities and Troika in May 2011. It was made official in a letter of intent and by two Memoranda of Understanding that detailed the general economic policy conditions (the "Memorandum of Understanding on Specific Economic Policy Conditionality", with the European Commission, and the "Memorandum of Economic and Financial Policies", with the IMF).

The total amount of funding was 78 billion euro's for the period of 20112014. The main goals were to improve productivity and competitiveness in the medium and long term; to ensure fiscal consolidation in the medium term; and to ensure the stability of the financial system.

According to the document "Portugal - EU/IMF Financial Assistance Programme" (Bank of Portugal 2011) the programme included more than four dozen terms and goals about macroeconomic policy, structural reforms and forms to strengthen the financial sector. Also it presented several limits to the growth of the public debt ratio (93\% in 2010 to $115 \%$ in 2013, decreasing thereafter) and the reduction of the public deficit ratio (9.1\% in 2010 to $5.9 \%$ in 2011, 4.5\% in 2012 and 3\% in 2013, to be achieved about one-third by increases in revenues and two-thirds by spending cuts).

\section{Effects on Economic Growth and Indebtedness}

Table 1 presents the growth rates of GDP and its main component (expenditure) variables in the period of 2008-2014. The depth of recession in the years of the crisis was clear: between 2008 and 2013 GDP decreased 8.3\%. After the agreement with Troika, between 2011 and 2013, GDP fell about $7.4 \%$, with figures already reflecting the effects of (excessive) austerity. In 2014, the growth was positive but still debilitated (under 1\%).

Table 1. GDP and Main Components (Expenditure), Real Growth Rate, 2008$2014(\%)$

\begin{tabular}{|l|c|c|c|c|c|c|c|}
\hline & $\mathbf{2 0 0 8}$ & $\mathbf{2 0 0 9}$ & $\mathbf{2 0 1 0}$ & $\mathbf{2 0 1 1}$ & $\mathbf{2 0 1 2}$ & $\mathbf{2 0 1 3}$ & $\mathbf{2 0 1 4}$ \\
\hline GDP & 0.2 & -3.0 & 1.9 & -1.8 & -4.0 & -1.6 & 0.9 \\
\hline Private consumption & 1.5 & -2.3 & 2.5 & -3.7 & -5.7 & -1.5 & 2.2 \\
\hline Public consumption & 0.4 & 2.6 & -1.3 & -3.7 & -3.3 & -2.4 & -0.3 \\
\hline Investment & 0.8 & -12.2 & 3.4 & -14.0 & -18.1 & -6.7 & 5.3 \\
\hline Domestic demand & 1.2 & -3.5 & 1.8 & -5.7 & -7.3 & -2.5 & 2.1 \\
\hline $\begin{array}{l}\text { Exports of goods and } \\
\text { services }\end{array}$ & -0.3 & -10.2 & 9.5 & 7.0 & 3.4 & 6.4 & 3.3 \\
\hline $\begin{array}{l}\text { Imports of goods and } \\
\text { services }\end{array}$ & 2.4 & -9.9 & 7.8 & -5.8 & -6.3 & 3.9 & 6.4 \\
\hline
\end{tabular}

Source: Bank of Portugal (www.bportugal.pt).

\footnotetext{
${ }^{1}$ As a result there was a political crisis and legislative elections in June 2011. In this election the centre-right Social Democratic Party, led by Pedro Passos Coelho, had a victory over the Socialist Party, led by the incumbent Prime Minister José Sócrates.
} 
It is also worth noting that the performance, in general, of the external trade balance was good (increase in exports and decrease in imports).

The evolution of the public finances in the period of 2008-2014, presented in Figure 6, shows that the budget balance deficit (\% of GDP) was $3.8 \%$ in 2008 and attained its highest value in the year before the presence of Troika (11.2\% in 2010). As a result of the adjustment process, the public deficit has decreased since 2011 , being $4.5 \%$ in 2014 .

Concerning the public debt (\% of GDP), as we have seen previously, Portugal began with a relatively low debt, which surpassed $60 \%$ in 2004 . In the years of crisis, the public debt increased continuously, particularly after the borrowing from Troika and, in the last two years, Portugal has already displayed high levels of debt (about 130\% of GDP).

Figure 6. Overall Budget Balance and Public Debt, 2008-2014 (\% of GDP)

Overall budget balance

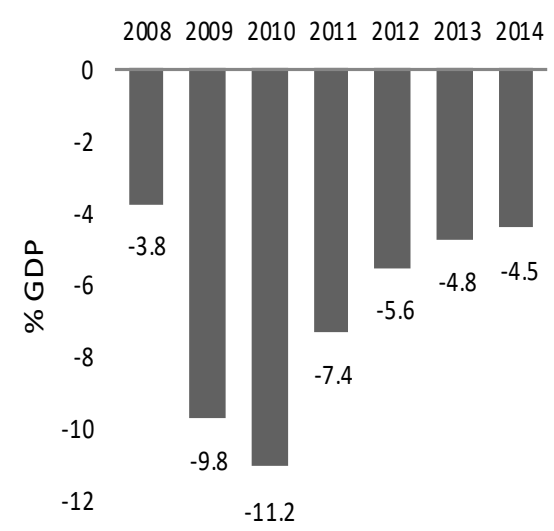

Public Debt

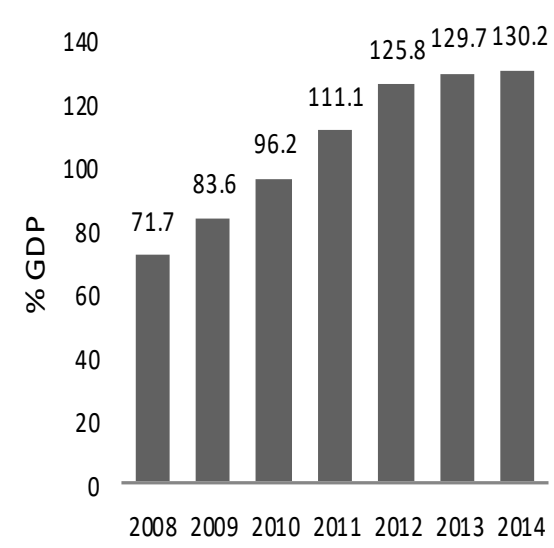

Source: Bank of Portugal (www.bportugal.pt).

Regarding the external indebtedness, Figure 7 shows that Portugal was able to move from a trade balance with deficits of $10 \%$ of GDP to surpluses. Between 2010 and 2013 there was an improvement of 11 percentage points in the trade balance (\% of GDP), which was the largest among the EU countries. In the last two years Portugal displayed a surplus in its external current account (including the trade balance). ${ }^{2}$

\footnotetext{
${ }^{2}$ The Annual Report from Bank of Portugal (2014) includes a detailed analysis about the process of accumulation of debt of the various institutional sectors prior to and during the crisis.
} 
Figure 7. External Current Account and Trade Balance, \% of GDP, 20082014

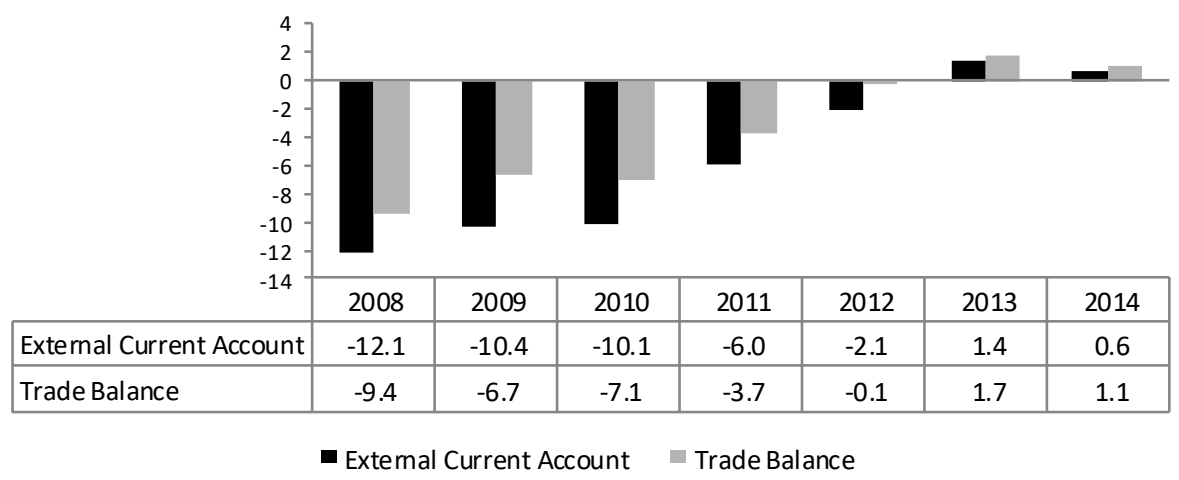

Source: Bank of Portugal (www.bportugal.pt).

Effects on Labour Market

With regard to the labour market (Table 2), the conditions have deteriorated substantially with unemployment displaying a growth trend. As mentioned earlier, when Portugal joined the euro area the rate of unemployment had a value around 4\%. In 2013, the value more than quadrupled to $16.4 \%$. Unemployment increased substantially during the years of crisis, when it appeared to be very sensitive to the deceleration of economic activity and to the sovereign debt crisis. In this period, the number of unemployed persons nearly doubled, from 459,000 in 2008 to 855,000 persons in $2013 .^{3}$

Table 2. Selected Labour Market Indicators, 2008-2013

\begin{tabular}{|l|c|c|c|c|c|c|}
\hline & $\mathbf{2 0 0 8}$ & $\mathbf{2 0 0 9}$ & $\mathbf{2 0 1 0}$ & $\mathbf{2 0 1 1}$ & $\mathbf{2 0 1 2}$ & $\mathbf{2 0 1 3}$ \\
\hline Total unemployment (thousands) & 459 & 569 & 645 & 688 & 836 & 855 \\
\hline $\begin{array}{l}\text { Unemployment rate (\% labour } \\
\text { force) }\end{array}$ & 8.5 & 10.6 & 12.0 & 12.9 & 15.8 & 16.4 \\
\hline $\begin{array}{l}\text { Long-term unemployment (\%) } \\
\text { labour force) }\end{array}$ & 4.0 & 4.7 & 6.3 & 6.2 & 7.7 & 9.3 \\
\hline $\begin{array}{l}\text { Youth unemployment rate (\% } \\
\text { labour force 15-24) }\end{array}$ & 20.5 & 25.1 & 28.2 & 30.3 & 37.9 & 38.1 \\
\hline $\begin{array}{l}\text { Fixed term contracts (\% total } \\
\text { employees) }\end{array}$ & 22.8 & 22.0 & 23.0 & 22.2 & 20.7 & 21.5 \\
\hline $\begin{array}{l}\text { Part-time employment (\% total } \\
\text { employment) }\end{array}$ & 11.9 & 11.6 & 11.6 & 13.3 & 14.3 & 14.0 \\
\hline Total employment (thousands) & 5147 & 5014 & 4937 & 4861 & 4656 & 4525 \\
\hline
\end{tabular}

Source: European Commission (2015).

\footnotetext{
${ }^{3}$ According to IMF (2015) if involuntary part-time work and "discouraged" people (i.e. who while waiting work were not actively seeking work) were to be considered in the calculation of the Portuguese unemployment rate it would be increased to around $10 \%$ in 2013.
} 
Another related problem is the great decrease, in net terms, of employment: in five years about 622,000 jobs were lost. This contributed to the average unemployment rate remaining at a very high level.

Table 2 illustrates another relevant feature of the Portuguese labour market: the sharp increase of long-term unemployment, which more than doubled during the crisis years. This made the incidence of long-term unemployment in Portugal one of the highest in OECD countries (OECD 2014). In fact, the rate of unemployment for 12 months or more rose sharply, reaching $9.3 \%$ in 2013 , i.e. more than half of those seeking employment were unemployed for at least one year.

This represents a serious problem for the Portuguese economy, because long-term unemployment tends to lead to a sharp devaluation of the human capital, with adverse effects on economic growth. Moreover, long-term unemployment "involves highly relevant personal and social costs and induces the depreciation of professional skills and poverty and social exclusion, which reduce society's capacity to undertake structural transformations and adopt correct economic policies" (Bank of Portugal 2014: 21).

The worsening of unemployment was particularly felt by young people, with an exponential increase in their unemployment rate, which almost doubled in the 2008-2013 period: the unemployment rate for 15-24-year-olds reached a peak of $38.1 \%$ in 2013.

Table 2 also shows another of the most important developments in recent years in the Portuguese labour market: its high level of segmentation that is reflected in the high incidence of employment in part-time and fixed-term contracts (14\% and $21.5 \%$ in 2013 , respectively). ${ }^{4}$ In this area, Portugal followed other European countries and also created a dual labour market, with different contracts and protections in employment and unemployment for different groups of workers. In one segment of the market there are temporary contracts which mostly apply to young and less experienced workers and, on the other, permanent jobs for the more skilled and experienced workers (Centeno and Novo 2012).

Concerning long-term unemployment, the growth of temporary contracts is particularly worrying. The incidence of this type of contracts may have a negative impact on the economy because workers with these contracts have a smaller degree of employment protection than employees with open-ended contracts. Additionally, firms tend to spend less in training temporary workers which might have negative implications in productivity growth.

The recent policies adopted in the labour market have resulted in the reduction of the employment protection gap between open-ended contracts and fixed-term contracts. However, this gap could be narrowed further (OECD 2014).

In summary, during the crisis years there has been a great increase in unemployment and a significant destruction of jobs. The gravity of the labour

\footnotetext{
${ }^{4}$ Fixed-term contracts were introduced in Portugal in the 1980s and, during the 1990s, the rules for using temporary contracts were made more flexible, contrasting with the protection afforded to permanent jobs, which hardly changed (Bank of Portugal 2015).
} 
market situation is greater due to several constraints: 1 . most of the unemployment is long-lasting; 2 . it has significantly increased the number of young people who are not employed, studying, or training; 3. the labour market displayed a strong segmentation, i.e. a more qualified segment tends to have better conditions of employment and quality of jobs versus a less qualified segment with maladjusted qualifications to the needs of the productive sector, at risk of structural unemployment or greater precariousness in employment.

\section{Effects on Wages and Inequality}

The wage adjustment in the crisis years involved a relative slowdown in the growth of nominal wages and substantial cuts in real wages since 2010 (Figure 8). ${ }^{5}$

Figure 8. Nominal and Real Average Wages, 2008-2013 (index)

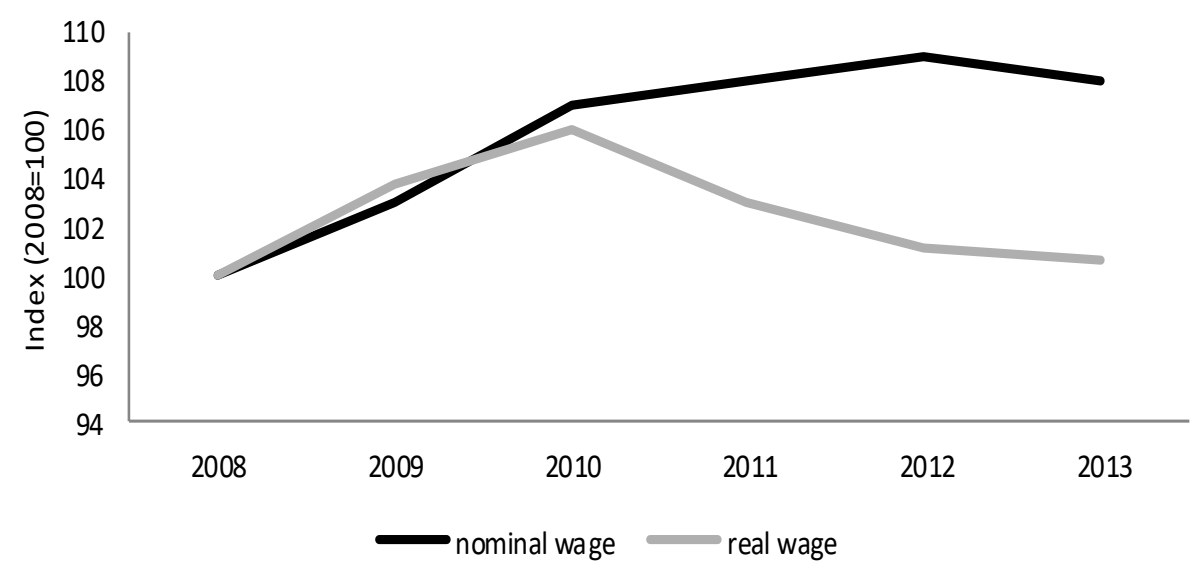

Source: PORDATA - Database of Contemporary Portugal (www.pordata.pt).

The growth of nominal wages was about 3-4\% until 2010 and has moderated to $-1-1 \%$ since then. ${ }^{6}$ The cuts in real wages affected nearly twothirds of the Portuguese workforce in 2010 due to the adjustment programme agreed with Troika (OECD 2014).

Additionally, while the EFAP was effective, the increase of pensions was moderate (a few minimum pensions were increased, the remaining were frozen, and the highest ones were cut).

While this helped restore competitiveness, it also caused considerable hardships, especially among low-paid workers and their families, affecting the

\footnotetext{
${ }^{5}$ The data refers to average monthly earnings of full-time employees with full remuneration. Regarding central, regional and local administration services and public institutes, the figures presented include only employees recruited via individual work contracts.

${ }^{6}$ The slowdown of unit labour costs growth in Portugal was in process before the crisis. For example, Gouveia and Correia (2013), analysing labour costs convergence in the euro area since 1995, concluded that, after the circulation of the euro, Portugal reduced considerably the differential in nominal compensation per employee growth and in nominal unit labour costs growth relative to euro area.
} 
levels of inequality in Portugal. In the last OECD report on inequality (OECD 2015), Portugal occupied the seventh place among 30 countries (in 2013). According to this OECD document, household income inequality and poverty increased in the countries most affected by the crisis (such as Portugal, Greece, Ireland and Spain) due to the implementation of fiscal consolidation programmes, although the impact has depended much on the tax system and specific measures launched during this period.

Wage reductions (very substantial for the public workers) and the tax burden, including alterations in the tax on personal income and the imposition of an extra charge on income from work, contributed to the increase of the risk of poverty and social exclusion (from $26 \%$ in 2008 to $27.5 \%$ of total population in 2013). ${ }^{7}$ This impoverishment particularly affected the lower middle class, which became more vulnerable to the austerity measures and to unemployment.

The decline and instability in employment and more restrictive rules for access to unemployment benefits (the unemployment benefit amount and duration were reduced) are another relevant explanation for the increase in inequality.

Troika left Portugal a year ago, and in September 2014 (against Troika's will) the Portuguese government reached agreement with social partners to increase the minimum wage from 485 euros to 505 euros per month, starting in October 2014. However, it does not overlay the tendency for the diminution or, at least, the stagnation of real wages. It's expected that this tendency will continue in the near future as the increase of temporary work and the number of workers receiving minimum wage are important factors in pulling down wages. The same applies to the drop in the number of unionised workers.

\section{Demographic Effects}

Over the period of 2008-2013 the Portuguese economy has been characterised by marked demographic developments: a fall in birth rates and an increase in life expectancy - with consequent implications for the population in an active age - and changes in migration flows (Table 3 ).

The intensification of the emigration phenomenon is one of the most important recent transformations in the Portuguese economy. Looking at Table 3 , it is evident that permanent emigration has been steadily increasing since 2009, almost doubling in 2011 and continuing to grow in the period after.

Considering total emigration (temporary and permanent), between 2011 and 2013, 350,000 people left Portugal! It should be noted that most emigrants are young, and many of them have high qualifications. In consequence, the share of remittances in GDP has recently (after 2012) increased, reversing a situation of decline since the 1980s. In 2013 remittances were $1.8 \%$ of GDP and surpassed 3 billion euros (Correia and Teixeira 2014).

\footnotetext{
${ }^{7}$ See the Eurostat database (http://bit.ly/1vbibQq).
} 
Table 3. Selected Demographic Indicators, 2008-2013 (thousands)

\begin{tabular}{|l|c|c|c|c|c|c|}
\hline & $\mathbf{2 0 0 8}$ & $\mathbf{2 0 0 9}$ & $\mathbf{2 0 1 0}$ & $\mathbf{2 0 1 1}$ & $\mathbf{2 0 1 2}$ & $\mathbf{2 0 1 3}$ \\
\hline Total population & 10623 & 10638 & 10636 & 10647 & 10600 & 10499 \\
\hline Population aged 15-64 & 7145 & 7143 & 7114 & 7097 & 7038 & 6961 \\
\hline Net increase & 9.7 & 10.5 & -0.8 & -30.3 & -55.1 & -60.0 \\
\hline Natural increase & 0.3 & -4.9 & -4.6 & -6.0 & -17.8 & -23.8 \\
\hline Net migration & 9.4 & 15.4 & 3.8 & -24.3 & -37.3 & -36.2 \\
\hline Variation of foreign population & 34.4 & 15.7 & -8.7 & -8.3 & -20.1 & -16.3 \\
\hline Permanent emigrants & 20.4 & 16.9 & 23.8 & 44.0 & 52.0 & 53.8 \\
\hline Temporary emigrants & n.d. & n.d. & n.d. & 57.0 & 69.5 & 74.3 \\
\hline Total emigrants & n.d. & n.d. & n.d. & 101.0 & 121.4 & 128.1 \\
\hline
\end{tabular}

* n.d.: not available data.

Source: European Commission (2015), National Statistics Office (www.ine.pt), PORDATA -

Database of Contemporary Portugal (www.pordata.pt).

\section{The Medium Term: Challenges and Opportunities for Portugal}

The conclusion in May 2014 of the EFAP was a landmark in the evolution of the Portuguese economy. In this section we examine the projections for the medium term and focused on the challenges and opportunities for Portugal in the near future.

\section{Projections}

The negative implications of the crisis, which were aggravated by the austerity measures that have particularly affected public sector employment and social expenditure, make the recovery more uncertain and fragile.

All the spring 2015 projections (made by Eurostat, Portuguese Government, and IMF) consider that the Portuguese economy will have moderate growth and high unemployment in the medium term (Table 4).

Table 4. Projections for the Portuguese Economy, 2015-2016

\begin{tabular}{|l|c|c|c|c|c|c|}
\hline & \multicolumn{2}{|c|}{$\begin{array}{c}\text { European } \\
\text { Commission }\end{array}$} & \multicolumn{2}{c|}{$\begin{array}{c}\text { Portuguese } \\
\text { Government }\end{array}$} & \multicolumn{2}{c|}{ IMF } \\
\hline & 2015 & 2016 & 2015 & 2016 & 2015 & 2016 \\
\hline GDP - real growth (\%) & 1.6 & 1.8 & 1.6 & 2.0 & 1.6 & 1.5 \\
\hline Inflation rate (\%) & 0.2 & 1.3 & -0.2 & 1.3 & 0.6 & 1.3 \\
\hline $\begin{array}{l}\text { Unemployment rate } \\
(\%)\end{array}$ & 13.4 & 12.6 & 13.2 & 12.7 & 13.1 & 12.6 \\
\hline $\begin{array}{l}\text { Budget balance (\%) } \\
\text { GDP) }\end{array}$ & -3.1 & -2.8 & -2.7 & -1.8 & -3.2 & -2.8 \\
\hline Public deficit (\% GDP) & 124.4 & 123.0 & 124.2 & 121.5 & 126.3 & 124.3 \\
\hline
\end{tabular}

Source: European Commission (ec.europa.eu), Ministry of Finance - Stability Programme 2015-2019 (www.gpeari.min-financas.pt), IMF (www.imf.org).

In the next few years the Portuguese rate of unemployment will be around $13 \%$, continuing to be too high. But the real figure is even higher, because among employees, some are working fewer hours than they want, some unemployed may have a reduced ability to seek employment, and among the 
inactive there are those who want to work if there are jobs available. As mentioned in the last section, these realities became very significant in the crisis years.

Another substantial problem that remains in the medium term is the very heavy public debt ratio (more than $120 \%$ of GDP!).

The objectives of Troika in 2011 were to address the lack of funding in the country and, at the same time, to end the structural weaknesses of the economy, setting it to grow faster. However, according to the IMF (2015), only the first goal has been met, i.e. Portugal was able to reduce the deficit and the country again received funding from the market. However, as recognised in this report of May 2015, four of the five priorities for the medium term were not yet achieved, namely: to ensure an internal balance (for example, to not have too high a rate of unemployment); to increase growth potential; to reduce private debt; and to ensure fiscal sustainability.

Only the priority of achieving external balance (not having excessive external deficits) has been fulfilled. So, the drawn trend is not optimistic. And there are even concerns over the external balance achieved in recent years, as the IMF warns that this may not be sustainable, because once the economy recovers, imports will probably recover.

\section{Challenges and Opportunities}

The great challenge to the Portuguese economy is to return to economic growth in a sustained manner. This is necessary to generate more employment and to reduce the high levels of unemployment prevailing in the economy, which is undoubtedly one of the most damaging dimensions of the adjustment process.

This would be a relatively simple problem if Portugal had preserved its own currency and could simply devalue its exchange rate to make its exports more competitive, as was done in the past. However, the Portuguese economy's evolution is heavily conditioned by the framework of the economic and financial policies of the EU, especially within the EMU. The recent changes in the European institutional framework, comprising the "Fiscal Compact", the creation of the Banking Union, and the European Stability Mechanism, have been designed to strengthen the sustainability of public finances and to create risk-sharing mechanisms (Bank of Portugal 2014). But, it should be noted that the efficacy of these changes in preventing and solving crises is contingent upon the member states' appropriation of a series of good practices in the implementation of domestic policies, which are greatly constrained by the Stability and Growth Pact. $^{8}$

\footnotetext{
${ }^{8}$ The crisis has motivated some proposals for strengthening the fiscal power of the EU. Several authors, such as De Grauwe $(2010,2013)$ and Allard et al. (2013) have argued that it is necessary to go further in the European integration process and has defended that a deeper political/fiscal union is essential for the survival of the euro area in the long run. However, as shown, for example, by Bordo et al. (2013), this is far from a consensual issue, having divergent views in debate.
} 
Another important challenge is the correction of accumulated imbalances and the restructuring of sectors and firms. The maintenance of these problems has delayed real convergence to the EU and has contributed to the deterioration of the income conditions of segments of Portuguese society.

The improvement in the quality of Portuguese institutions is also critical, namely to attract foreign direct investment and thus accelerate the growth process.

Finally, but not least important, the reducing of income inequality has emerged as a crucial and urgent goal. Income distribution is a key determinant for growth and, as pointed out by Dabla-Norris et al. (2015: 4) "... an increase in the income share of the bottom $20 \%$ (the poor) is associated with higher GDP growth. The poor and the middle class matter for growth via a number of interrelated economic, social and political channels".

Structural funds (2014-2020) are considered essential tools to support the country's development and to correct existing regional disparities which have increased as a consequence of the crisis. This should promote growth and employment, with the aim of reducing poverty and correcting the external imbalance that still exists (Portugal 2020 - Partnership Agreement 20142020).

\section{Conclusion}

The "Great Recession" strongly affected Portugal, as it did other European countries, from 2008 onward. Despite the effects of the crisis, which have substantially worsened the situation, many of the problems of the Portuguese economy came from the past. Namely, from the time Portugal joined the euro area until the outset of the global crisis it has experienced poor economic performance, excessive consumption growth, high external indebtedness, growing public indebtedness and lower investment and savings.

Comparing the situation in the present with the situation before the economic and sovereign debt crisis, data show clearly that the conditions have deteriorated substantially. Namely the GDP has declined greatly and unemployment has reached historically high levels. This great increase in unemployment should be highlighted as the most serious consequence of the crisis, since it brought poverty and more inequality.

The recession has influenced social and economic groups in different ways. In general, women, youth, less skilled workers, migrant workers and older people have been the most adversely affected (by job losses and cuts in benefits, wages and pensions).

The analysis carried out in this paper suggests that the current situation in the Portuguese economy is due to the country's choices made in the past and the recent failure to address structural problems, particularly competitiveness and high debt levels. But it is also the responsibility of the austerity measures imposed by the Troika, which worsened the problems. 
Today, Portugal is at one of the most difficult and decisive moments in its recent history. If it follows the path of austerity (suggested by some national and international institutions) in order to balance its public finances, this means more unemployment, more emigration and lower economic growth, compromising/enhancing the country's economic and social weaknesses. Being within the euro area has made it more difficult to tackle these problems because Portugal has lost the control of the monetary policy that in the past had enabled it to devalue its currency when needed, namely in order to improve exports and competitiveness.

In the current context, it is essential that the euro area creates macroeconomic stabilisation instruments with appropriate financing solutions and the ability to support its member states in implementing the necessary structural reforms. Some euro area countries, namely those that were more sensitive to the crisis, as in the case of Portugal, need more attention in order to recuperate from this deep and long recession.

\section{Acknowledgements}

This work is supported by national funds provided by the FCT Portuguese Foundation for Science and Technology, through its project UID/SOC/04011/2013.

\section{References}

Allard C, Brooks P, Bluedorn J, Bornhorst F, Christopherson K, Ohnsorge F, Poghosyan T, IMF staff team (2013) Toward a Fiscal Union for the Euro Area. IMF Staff Discussion Note.

Bank of Portugal (2011) Portugal - EU/IMF Financial Assistance Programme, 20112014. Lisbon: Bank of Portugal.

Bank of Portugal (2014) Annual Report: The Portuguese Economy. Lisbon: Bank of Portugal.

Bank of Portugal (2015) The Portuguese Labour Market and the Great Recession. Economic Bulletin May 2015 Special issue: 73-91.

Bordo M, Markiewicz A, Jonung L (2013) A fiscal union for the euro: some lessons from history. CESifo Economic Studies 59 (3): 449-488.

Centeno M, Novo A (2012) Excess worker turnover and fixed-term contracts: causal evidence in a two-tier system. Labour Economics 19 (3): 320-328.

Claessens S, Kose MA, Terrones ME (2009) What happens during recessions, crunches and busts? Economic Policy 60: 653-700.

Claessens S, Kose MA, Terrones ME (2010) The global financial crisis: How similar? How different? How costly? Journal of Asian Economics 21: 247-264.

Correia L, Teixeira C (2014) Migration flows, remittances and business cycles: an analysis with application to the Portuguese case. Proceedings from the 20th APDR Congress: 1060-1074.

Dabla-Norris E, Kochhar K, Suphaphiphat N, Ricka F, Tsounta E (2015) Causes and Consequences of Income Inequality: a Global Perspective. IMF Staff Discussion Note 15/13. 
De Grauwe P (2010) The fragility of the eurozone's institutions. Open Economies Review 21: 167-174.

De Grauwe P (2013) The political economy of the euro. Annual Review of Political Science 16: 153-170.

European Commission (2009) Economic Crisis in Europe: Causes, Consequences and Responses. European Economy 7.

European Commission (2015) Employment and Social Developments in Europe 2014. Directorate-General for Employment, Social Affairs and Inclusion, European Union.

Gibson HD, Palivos T, Tavlas GS (2014) The crisis in the euro area: an analytic overview. Journal of Macroeconomics 39: 233-239.

Gouveia S, Correia L (2013) Labour costs dynamics in the euro area: some empirical evidence. International Economics and Economic Policy 10(3): 323-347.

Grossman R, Meissner C (2010) International aspects of the Great Depression and the crisis of 2007: similarities, differences, and lessons. Oxford Review of Economic Policy 26(3): 318-338.

Honkapohja S (2014) The euro area crisis: a view from the North. Journal of Macroeconomics 39: 260-271.

IMF (2015) Portugal: First Post-Program Monitoring Discussions. Staff Report, Press Release, and Statement by Executive Director. Country Report No. 15/21.

Kenc T, Dibooglu S (2010) The 2007-2009 financial crisis, global imbalances and capital flows: implications for reform. Economic Systems 34: 3-21.

Moro B (2014) Lessons from the European economic and financial great crisis: a survey. European Journal of Political Economy 34: S9-S24.

Obstfeld M (2013) Crises and the international system. International Economic Journal 27(2): 143-155.

OECD (2014) OECD Employment Outlook 2014: How Does Portugal Compare? http://www.oecd.org/portugal/EMO-PRT-EN.pdf

OECD (2015) In It Together: Why Less Inequality Benefits All. Paris: OECD Publishing. DOI= http://dx.doi.org/10.1787/9789264235120-en.

Papanikos GT (2014) The Greek Sovereign Debt: Are There Really Any Options? ATINER's Conference Paper Series CBC2014-1324.

Portugal 2020 - Partnership Agreement 2014-2020. Retrieved from http://bit.ly/1Tud0Iy. [Accessed July 2014].

Santillán-Salgado RJ (2013) A Fundamental Interpretation of the 2009-2012 Crisis of the Eurozone. ATINER's Conference Paper Series ECO2013-0792.

United Nations (2011) The Global Social Crisis: Report on the World Social Situation. New York: Department of Economic and Social Affairs, United Nations. 